\title{
Pengaruh Pemberian Vitamin C terhadap Perubahan Kadar Total Antioksidan Serum pada Penderita Tuberkulosis Paru Anak
}

\author{
Eki Rakhmah Zakiyyah, Dida A Gurnida, Cissy B Kartasasmita \\ Departemen Ilmu Kesehatan Anak Fakultas Kedokteran Universitas Padjadjaran/ Rumah Sakit Dr. Hasan \\ Sadikin, Bandung
}

\begin{abstract}
Latar belakang. Pada penderita tuberkulosis (TB) paru, terjadi peningkatan Reactive Oxygen Species (ROS) yang menyebabkan kebutuhan antioksidan meningkat sehingga terjadi penurunan kadar antioksidan serum. Pemberian vitamin $\mathrm{C}$ dapat meningkatkan kadar total antioksidan serum.

Tujuan. Mengetahui pengaruh vitamin $C$ terhadap kadar total antioksidan serum pada penderita TB paru.

Metode. Penelitian uji klinis samar tunggal acak terkontrol dilaksanakan bulan April-Juli 2013. Tigapuluh orang penderita TB paru yang baru didiagnosis dilibatkan, berusia 1-14 tahun. Penelitian dilakukan di poli anak Rumah Sakit Dr. Hasan Sadikin Bandung dan RSUD Cibabat, Dibagi 2 kelompok, yaitu mendapat vitamin $\mathrm{C}$ dan plasebo, dilakukan selama 2 minggu. Pemeriksaan kadar total antioksidan serum dilakukan sebelum dan sesudah pemberian vitamin $\mathrm{C}$ dan plasebo. Perhitungan statistik dengan analisis varian twoway ANOVA digunakan untuk menganalisis perubahan kadar total antioksidan serum berdasarkan waktu (faktor A), pengaruh perlakuan (faktor B), dan interaksi di antara keduanya.

Hasil. Subjek terdiri dari 22 anak laki-laki dan 8 perempuan. Tidak terdapat perbedaan bermakna pada usia, jenis kelamin, berat badan, tinggi badan, status gizi, dan asupan gizi pada kedua kelompok. Terdapat perbedaan bermakna pada perubahan kadar total antioksidan serum berdasarkan waktu $(\mathrm{p}=0,01)$ dan interaksi antara perubahan kadar total antioksidan serum berdasarkan waktu dengan perlakuan $(\mathrm{p}=0,01)$.

Kesimpulan. Penelitian ini menunjukkan pemberian vitamin $\mathrm{C}$ bermanfaat dalam meningkatkan kadar total antioksidan serum pada penderita TB paru. Sari Pediatri 2014;16(2):110-4.
\end{abstract}

Kata kunci: tuberkulosis paru anak, total antioksidan serum, suplementasi, vitamin C

\footnotetext{
Alamat korespondensi:

Dr. Eki Rakhmah Zakiyyah, M.Kes. Departemen Ilmu Kesehatan Anak Fakultas Kedokteran Universitas Padjadjaran/Rumah Sakit Dr. Hasan Sadikin Jl. Pasteur No. 38 Bandung 40163. Telp. (022) 2035957/08122197507. E-mail: rakhmahz@gmail.com
}

uberkulosis (TB) merupakan salah satu
penyebab angka kesakitan dan kematian
yangtinggi, terutama di negara berkembang. ${ }^{1}$
Tuberkulosis adalah penyakit infeksi
disebabkan Mycobacterium tuberculosis, lebih sering

Sari Pediatri, Vol. 16, No. 2, Agustus 2014 
menyerang paru, tetapi dapat menyerang organ lain. Patogenesis TB bersifat multifaktorial dan termasuk di dalamnya adalah stres oksidatif. Pada penderita TB terjadi hiperaktivasi makrofag akibat infeksi Mycobacterium tuberculosis. Selama fagositosis, Mycobacterium makrofag melepaskan Reactive Oxygen Species (ROS) termasuk $\mathrm{H}_{2} \mathrm{O}_{2}$, superoksid, dan spesies nitrogen reaktif. Apabila tubuh tidak dapat mengatasi hiperaktivasi ini, akan menimbulkan stres oksidatif yang menyebabkan ketidakseimbangan oksidan dan antioksidan. ${ }^{2-4}$

Penelitian Reddy $\mathrm{dkk}^{5}$ menyatakan antioksidan yang sering ditemukan rendah pada penderita TB paru adalah glutation, asam askorbat (vitamin C), dan $\alpha$-tokoferol (vitamin E). Penelitian Johnkennedy dkk ${ }^{6}$ menyatakan bahwa penderita tuberkulosis ditemukan kadar vitamin C dan E rendah. Penurunan salah satu kadar antioksidan ini akan menyebabkan penurunan kadar total antioksidan serum pada penderita TB. Kadar antioksidan rendah disebabkan asupan kurang pada penderita TB paru dan peningkatan radikal bebas selama proses fagositosis Mycobacterium.

Pada penderita TB, pemberian antioksidan dapat memengaruhi penyembuhan penyakit melalui mekanisme perbaikan fungsi sel $\mathrm{T}$ dan menurunkan produksi prostaglandin E2 serta menekan efek radikal bebas. Pada penderita TB yang mendapat antioksidan ditemukan status antioksidan meningkat dan terjadi penurunan stres oksidatif. Contoh antioksidan yang sering digunakan adalah vitamin $\mathrm{C}$ yang berperan besar dalam memengaruhi fungsi imun dan pertahanan tubuh, serta melindungi lipid dari proses oksidasi. Vitamin C sebaiknya diberikan dalam waktu 14 hari supaya dapat meningkatkan kadar vitamin $\mathrm{C}$ dalam darah dan dapat meningkatkan kadar total antioksidan serum..$^{7-10}$ Tujuan penelitian ini adalah mengetahui pengaruh pemberian vitamin $\mathrm{C}$ terhadap perubahan kadar total antioksidan serum pada penderita TB paru anak.

\section{Metode}

Penelitian uji klinis samar tunggal acak terkontrol dilaksanakan sejak bulan April 2013 hingga Juli 2013 di unit rawat jalan Departemen Ilmu Kesehatan Anak Rumah Sakit Hasan Sadikin Bandung dan Rumah Sakit Umum Daerah Cibabat. Lembar persetujuan (informed consent) ditandatangi oleh orangtua yang telah mendapat penjelasan dan menyetujui anaknya ikut dalam penelitian. Kriteria inklusi adalah penderita TB baru rawat jalan yang sudah didiagnosis TB paru usia 1 tahun sampai dengan 14 tahun. Kriteria eksklusi adalah penderita TB yang telah menjalani terapi obat anti tuberkulosis (OAT), gizi buruk, dan mengidap penyakit kronik lain secara klinis.

Subjek penelitian dibagi 2 kelompok, yaitu kelompok yang mendapat vitamin $\mathrm{C}$ dengan dosis berdasarkan Recommended Dietary Allowance (RDA) dan kelompok yang mendapat plasebo. Kadar total antioksidan serum diperiksa dengan metode kolorimetri menggunakan reagen Randox. Asupan gizi setiap subjek penelitian dianalisis dengan Food Frequency Questionnaire (FFQ).

Perhitungan statistik menggunakan analisis varian dengan two-way ANOVA untuk melihat perubahan kadar total antioksidan serum berdasarkan waktu (Faktor A), pengaruh perlakuan (Faktor B), dan interaksi keduanya. Data statistik dihitung menggunakan program SPSS versi 17.0 dengan nilai $\mathrm{p}<0,05$ menunjukkan perbedaan bermakna. Penelitian dimulai setelah mendapatkan persetujuan Komite Etik Penelitian Kesehatan Fakultas Kedokteran Universitas Padjadjaran/RS Dr. Hasan Sadikin Bandung.

\section{Hasil}

Tiga puluh penderita TB paru terdiri atas 22 orang laki-laki dan 8 orang perempuan yang memenuhi kriteria inklusi. Karakteristik subjek penelitian tertera pada Tabel 1.

Berdasarkan Tabel 1 terlihat bahwa tidak terdapat perbedaan yang bermakna antara usia, jenis kelamin, berat badan, tinggi badan, dan status gizi di antara kedua kelompok. Data karakteristik asupan gizi subjek penelitian meliputi energi, protein, Fe, vitamin A, vitamin B1, dan vitamin C tertera pada Tabel 2.

Berdasarkan Tabel 2 dapat dilihat asupan gizi pada kedua kelompok menunjukkan tidak ada perbedaan bermakna. Rata-rata kadar total antioksidan serum pada kelompok yang mendapatkan vitamin $\mathrm{C}$ $(1,25 \pm 0,022$ menjadi $1,34 \pm 0,023)$ dengan kelompok plasebo $(1,25 \pm 0,038$ menjadi $1,29 \pm 0,039)$ sebelum dan sesudah perlakuan menunjukkan adanya peningkatan. Hasil tersebut tertera pada Tabel 3 dibawah ini. 
Tabel 1 Karakteristik subjek penelitian

\begin{tabular}{lccc}
\hline \multirow{2}{*}{ Karakteristik Subjek } & \multicolumn{2}{c}{ Kelompok } & $\mathrm{p}$ \\
\cline { 2 - 3 } & $\begin{array}{c}\text { Perlakuan } \\
(\mathrm{n}=15)\end{array}$ & $\begin{array}{c}\text { Kontrol } \\
(\mathrm{n}=15)\end{array}$ & \\
\hline Usia (bulan) & $68,73(46,3)$ & $56,93(37,8)$ & 0,160 \\
$\quad$ X(SB) & $12-137$ & $15-132$ & \\
$\quad$ Rentang & & & 0,116 \\
Jenis kelamin & 10 & 12 & \\
$\quad$ Laki-laki & 5 & 3 & 0,411 \\
$\quad$ Perempuan & & & \\
Berat badan (kg) & $16,31(7,19)$ & $14,57(6,03)$ & 0,105 \\
$\quad$ X (SB) & $8-29$ & $8-25$ & \\
$\quad$ Rentang & $102,8(23,07)$ & $98,93(17,34)$ & 1,000 \\
Tinggi badan (cm) & $71-138$ & $74-125$ & \\
$\quad$ X (SB) & & & \\
Rentang & 8 & 8 & \\
Status gizi (n) & 7 & 7 & \\
Kurang & & & \\
Baik & &
\end{tabular}

Keterangan: X: Rata-rata, SB: simpangan baku, p>0,05 : homogen

Tabel 2. Karakteristik asupan gizi

\begin{tabular}{|c|c|c|c|}
\hline Parameter & Perlakuan & Kontrol & $\mathrm{p}$ \\
\hline \multicolumn{4}{|c|}{ Energi (Kcal) } \\
\hline X (SB) & $1131,79(223,68)$ & $1207,77(226,91)$ & 0,615 \\
\hline Rentang & $749-1475$ & $935,8-1485,78$ & \\
\hline \multicolumn{4}{|c|}{ Protein (gram) } \\
\hline $\mathrm{X}(\mathrm{SB})$ & $48,31(14,31)$ & $51,07(11,89)$ & 0,513 \\
\hline Rentang & $18,32-65,69$ & $23,38-65,58$ & \\
\hline \multicolumn{4}{|c|}{ Vitamin A $(\mu \mathrm{g})$} \\
\hline $\mathrm{X}(\mathrm{SB})$ & $914,75(290,53)$ & $1580,84(691,09)$ & 0,015 \\
\hline Rentang & $193,59-1307,47$ & $1084,54-3318,19$ & \\
\hline \multicolumn{4}{|l|}{$\mathrm{Fe}(\mathrm{mg})$} \\
\hline $\mathrm{X}(\mathrm{SB})$ & $10,38(1,52)$ & $10,84(1,52)$ & 0,847 \\
\hline Rentang & $7,17-12,46$ & $8,81-14,81$ & \\
\hline \multicolumn{4}{|c|}{ Vitamin B1(mg) } \\
\hline $\mathrm{X}(\mathrm{SB})$ & $1,01(0,20)$ & $0,94(0,19)$ & 0,742 \\
\hline Rentang & $0,62-1,37$ & $0,60-1,15$ & \\
\hline \multicolumn{4}{|c|}{ Vitamin C (mg) } \\
\hline $\mathrm{X}(\mathrm{SB})$ & $48,92(5,53)$ & $47,50(6,61)$ & 0,475 \\
\hline Rentang & $40,9-59,72$ & $35,7-56,77$ & \\
\hline
\end{tabular}

Keterangan: X: rata-rata, $\mathrm{SB}$ : simpangan baku, $\mathrm{p}>0,05$ : homogen

Berdasarkan Tabel 3 terlihat tidak terdapat perbedaan bermakna pada perlakuan antara yang diberi vitamin $C$ dengan plasebo (faktor $B)(p=0,202)$. Terdapat perbedaan bermakna pada perubahan kadar total antioksidan serum berdasarkan waktu (faktor A) $(\mathrm{p}=0,001)$ dan interaksi antara perubahan kadar total antioksidan serum berdasarkan waktu dengan perlakuan $(\mathrm{p}=0,01)$. 
Eki Rakhmah Zakiyyah dkk: Pengaruh vitamin C terhadap perubahan kadar total antioksidan serum pada TB paru

Tabel 3. Kadar total antioksidan serum sebelum dan sesudah suplementasi vitamin C

\begin{tabular}{lcc}
\hline Faktor-A (Kadar total antioksidan serum \\
$\begin{array}{r}\text { berdasarkan waktu, } \\
\text { mean }(\mathrm{SD}), \mathrm{mmol} / \mathrm{L})\end{array}$ & $\begin{array}{c}\mathrm{A}_{1} \\
\text { (Kadar total antioksidan } \\
\text { serum sebelum } \\
\text { suplementasi) }\end{array}$ & $\begin{array}{c}\mathrm{A}_{2} \\
\text { (Kadar total antioksidan } \\
\text { serum setelah } \\
\text { suplementasi) }\end{array}$ \\
\hline $\begin{array}{l}\text { Faktor-B (Perlakuan) } \\
\mathrm{B}_{1} \text { (Kelompok suplementasi) }\end{array}$ & $1,25(0,022)$ & $1,34(0,023)$ \\
$\mathrm{B}_{2}$ (Kelompok plasebo) & $1,25(0,038)$ & $1,29(0,039)$ \\
\hline
\end{tabular}

Keterangan: Two-way ANOVA:

Faktor-A: $\mathrm{P}=0.001 \quad$ Faktor-B: $\mathrm{P}=0.202$ Interaksi faktor-A dan faktor-B: $\mathrm{P}=0.01$

\section{Pembahasan}

Peradangan merupakan respons perlindungan terhadap kerusakan sel/jaringan. Ractive Oxygen Species (ROS) seperti superoksida merupakan penyebab utama kerusakan sel termasuk apoptosis dan berhubungan dengan penyakit peradangan kronik. Sel paru merupakan sel yang mudah mengalami kerusakan akibat efek oksidan. Hal tersebut menunjukkan bahwa sel paru akan melepaskan berbagai mediator peradangan dan sitokin seperti Tumor Necrosis Factor- $\alpha$ (TNF $\alpha$ ), Interleukin (IL)-1, dan IL-8 yang memberikan respons terhadap stres oksidatif. ${ }^{11-13}$

Pada penderita TB paru, terjadi peningkatan produksi ROS yang merupakan konsekuensi terjadinya fagositosis selama infeksi Mycobacterium tuberculosis. Apabila tubuh tidak dapat mengatasi, hiperaktivasi ini akan menimbulkan stres oksidatif yang menyebabkan ketidakseimbangan oksidan dan antioksidan. ${ }^{14,15}$ Stres oksidatif yang terjadi menyebabkan peningkatan sitokin TNF- $\alpha$ yang menekan pusat lapar di hipotalamus sehingga menurunkan nafsu makan pada penderita TB. Keadaan ini akan menimbulkan penurunan kadar total antioksidan serum. ${ }^{16-18}$

Penelitian Johnkennedy $\mathrm{dkk}^{6}$ menyatakan bahwa pada penderita tuberkulosis ditemukan kadar vitamin $\mathrm{C}$ dan $\mathrm{E}$ rendah. Penurunan salah satu kadar antioksidan ini akan menyebabkan penurunan kadar total antioksidan serum pada penderita TB. Kadar antioksidan rendah disebabkan asupan kurang dan peningkatan radikal bebas selama proses fagositosis Mycobacterium. Pada penelitian ini didapatkan rerata kadar antioksidan serum rendah pada kedua kelompok sebelum diberikan perlakuan.

Terdapat perbedaan pada perubahan kadar total antioksidan serum berdasarkan waktu. Hal tersebut menunjukkan faktor waktu berpengaruh terhadap kadar total antioksidan serum. Keadaan ini terjadi karena pemberian antioksidan selama 2 minggu dapat menurunkan stres oksidatif, meningkatkan kadar vitamin $\mathrm{C}$ dalam darah, meningkatkan kadar total antioksidan serum, meningkatkan efektivitas obat anti TB dan meningkatkan hasil akhir terapi pada penderita TB. ${ }^{7}$ Hasil tersebut sesuai dengan penelitian Madhavi $\mathrm{dkk}^{7}$ yang menyatakan penderita TB yang mendapat antioksidan seperti vitamin $\mathrm{C}$ menunjukkan adanya peningkatan total antioksidan setelah pemberian antioksidan selama 2 minggu.

Faktor perlakuan tidak bermakna secara statistik terhadap kadar total antioksidan serum. Faktor perlakuan dengan faktor waktu berpengaruh terhadap kadar total antioksidan serum dan keduanya saling tergantung. Pemberian vitamin C sebagai suplementasi dapat menurunkan pembentukan radikal bebas melalui pencegahan pembentukan peroksidasi lipid. Penurunan peroksidasi lipid dapat meningkatkan kadar antioksidan di antaranya vitamin $\mathrm{C}$ dalam darah kemudian akan meningkatkan kadar total antioksidan serum. Penelitian ini sejalan dengan penelitian Pawar $\mathrm{dkk}^{10}$ yang menyatakan pemberian suplementasi vitamin $\mathrm{C}$ dapat menurunkan peroksidasi lipid pada plasma sehingga meningkatkan kadar antioksidan dalam darah. Penelitian Madhavi $\mathrm{dkk}^{7}$ menyatakan penderita TB yang mendapat suplementasi vitamin $\mathrm{C}$ ditemukan peningkatan kadar antioksidan dalam darah. Dengan demikian, pengaruh waktu dan perlakuan terhadap kadar total antioksidan serum saling berinteraksi.

Keterbatasan penelitian ini adalah tidak dilakukan perbandingan analisis asupan gizi sebelum dan sesudah perlakuan, sehingga data asupan gizi lebih akurat. Keterbatasan penelitian lainnya adalah tidak dilakukan pemeriksaan kadar vitamin $\mathrm{C}$ dan tidak dilakukan perbandingan dengan multivitamin lain yang ditemukan rendah pada penderita TB paru. 
Sebagai kesimpulan, peningkatan kadar total antioksidan serum lebih tinggi pada kelompok TB paru yang diberikan suplementasi vitamin $\mathrm{C}$ dibandingkan dengan yang tidak diberikan. Dengan demikian, pemberian vitamin $C$ dapat dipertimbangkan pada tata laksana TB paru karena meningkatkan kadar total antioksidan serum.

\section{Daftar pustaka}

1. Salazar GE, Schmitz TL, Cama R, Sheen P, Franchi LM, Centeno G, dkk. Pulmonary tuberculosis in children in a developing country. Pediatrics 2001;108:448-53.

2. Mokondjimobe E L-MB, Akiana J, Ndalla UO, DossouYovo R, Mboussa J. Biomarkers of oxidative stress adn personalized treatment of pulmonary tuberculosis: emerging role of gamma-glutamyltrasnferase. Adv in Pharmacol Sci 2012;12:1-7.

3. Turrens JF. Mitochondrial formation of reactive oxygen species. J Physiol 2003;2:335-9.

4. Wiid I, Seaman T, Hoal EG, Benade AJS, Van Helden PD. Total antioxidant levels are low during active tuberculosis and rise with anti-tuberculosis therapy. IUBMB 2004;56:1-8.

5. Reddy YN, Murthy SV, Krishna DR, Prabhakar MC. Role of free radicals and antioxidants in tuberculosis patients. Indian J Tuberc 2004;51:213-18.

6. Johnkennedy N, Onyinyechi AS, Chukwunyere NNE. The antioxidant status and lipid peroxidation product of newly diagnosed and 6 weeks follow up patient with pulmonary tuberculosis in Owerri, Imo state, Nigeria. Asian Pasific J Tropical Dis 2011;2:292-4.

7. Madhavi M, Samudram P, Kumar H, Victor L. Effect of antioxidant vitamins $\mathrm{C}$ dan $\mathrm{E}$ supplementation on its plasma levels and on lipid profile in pulmonary tuberculosis patient. Am J Infect Dis 2009;5:263-72.

8. Padayatty SJ, Katz A, Wang Y, Eck P, Kwon O, Je-Hyuk L. Vitamin $\mathrm{C}$ as an antioxidant: evaluation of its role in disease prevention. J Am Coll Nutr 2003;22:18-35.

9. Taneja NK, Dhingra S, Mittal A, Naresh M, Tyagi JS. Mycobacterium tuberculosis transcriptional adaptation, growth arrest and dormancy phenotype development is triggered by vitamin C. British J Nutr 2010;9:1-11.

10. Pawar BD, Suryakar AN, Khandelwal AS. K. Effect of micronutrients supplementation on oxidative stress and antioxidant status in pulmonary tuberculosis. Biomed Res 2011;22:455-9.

11. Allen RG, Tresini M. Oxidative stress and gene regulation. Free Radical Biol Med 2000;28:463-99.

12. Devasagayam TPA, Tilak TJ, Boloor KK, Sane SK, Ghaskadbi SS, Lele RD. Free radicals and antioxidants in human health: current status and future prospects. JAPI 2004;52:794-804.

13. Valado A, Pereira L, Tavares PC, Ribeiro CF. Effect of the intense anaerobic exercise on nitric oxide and malondialdehyde in studies of oxidative stress. International J Biol Biomed Engineer 2007;1:32-6.

14. Madebo T LB, Aukrust P, Berge RK. Circulating antioxidants and lipid peroxidation products in untreated tuberculosis patients in Ethiopia. Am J Clin Nutr 2003;9:117-22.

15. Lamsal M, Gautam N, Bhatta N, Toora BD, Bhattacharya SK, Baral N. Evaluation of lipid peroxidation product, nitrite and antioxidant levels in newly diagnosed and two months follow-up patients with pulmonary tuberculosis. Southeast Asian J Trop Med Public Health 2007;38:695703.

16. Suresh DR, Annam V, Pratibha K, Hamsaveena. Immunological correlation of oxidative stress markers in tuberculosi patients. Int J Biol Med Res 2010;4:185-7.

17. Moses AO, Emmanuel OO, Ganiyu AO, Fidelis AA, AO D. Assesment of antioxidants and nutritional status of pulmonary tuberculosis patiens in Nigeria. Eur J Gen Med 2008;5:208-11.

18. Lutsenko EA, Carcamo JM, Golde DW. Vitamin c prevents DNA mutation induced by oxidative stress. J Biol Chem 2002;277:16895-9 